\title{
Vaccination access in Primary Care from the user's perspective: senses and feelings about healthcare services
}

\author{
Acesso à vacinação na Atenção Primária na voz do usuário: sentidos e sentimentos frente ao \\ atendimento
}

\section{Acceso a la vacunación en la Atención Primaria en la voz del usuario: sentidos y sentimientos} frente a la atención

\section{Deborah Correia Duarte ${ }^{1}$ Valéria Conceição de Oliveira ${ }^{1}$ (1) \\ Eliete Albano de Azevedo Guimarães ${ }^{1}$ (ID Selma Maria da Fonseca Viegas ${ }^{1}$ (D)}

1. Universidade Federal de São João Del-Rei. Divinópolis, MG, Brasil.
Corresponding author:

Selma Maria da Fonseca Viegas.

E-mail: selmaviegas@ufsj.edu.br

Submitted on $08 / 20 / 2018$.

Accepted on 10/06/2018.

DOI: 10.1590/2177-9465-EAN-2018-0250

\begin{abstract}
Objective: To understand the feelings, senses, perceptions and perspectives of Users regarding access to vaccination in Primary Health Care. Method: This is a Holistic-Qualitative Multiple Case Study, based on Comprehensive Sociology of Everyday Life with 74 participants representing four microregions of health in the Western Extended Region of Minas Gerais. Data collection occurred between June 2016 and April 2017. In order to analyse the data, we used the Thematic Content Analysis, obeying the technique of cross-synthesis of the cases. Results: The results reveal the senses perceived by Users in the experience of vaccination and the feelings regarding care, showing that interpersonal relations between population and health professionals are determinant in the access to vaccination. The constant expansion of the official immunization schedule increased access, however, geographical and social aspects, the lack of knowledge about vaccination and the recurrent lack of immunobiological were referred to as barriers to immunization access. Final considerations: We emphasized the need to reinforce more equitable policies and effective communication as a means to promote the credibility of the services with Users.
\end{abstract}

Keywords: Health Services Accessibility; Vaccination; Primary Health Care; Patient Satisfaction.

\section{REsUMO}

Objetivo: Compreender os sentimentos, sentidos, percepções e perspectivas de usuários frente ao acesso à vacinação na Atenção Primária à Saúde. Método:Trata-se de um Estudo de Casos Múltiplos Holístico-Qualitativo, fundamentado na Sociologia Compreensiva do Cotidiano com 74 participantes representantes de quatro microrregiões de saúde da Região Ampliada Oeste de Minas Gerais. A coleta de dados ocorreu entre junho de 2016 e abril de 2017. Para a análise dos dados, utilizou-se a Análise de Conteúdo Temática, obedecendo à técnica da síntese cruzada dos casos. Resultados: Os resultados revelam os sentidos percebidos pelos usuários na vivência em vacinação e os sentimentos frente ao atendimento, evidenciando que as relações interpessoais entre a população e os profissionais de saúde são determinantes no acesso à vacinação. A constante ampliação do calendário básico de imunização ampliou o acesso, entretanto, aspectos geográficos e sociais, a falta de conhecimento sobre vacinação e a recorrente falta de imunobiológico foram referidos como barreiras ao acesso à imunização. Considerações finais: Ressalta-se a necessidade de reforçar políticas mais equitativas e a comunicação efetiva como meio de promover a credibilidade dos serviços junto aos usuários.

Palavras-chave: Acesso aos Serviços de Saúde; Vacinação; Atenção Primária à Saúde; Satisfação do Paciente.

\section{Resumen}

Objetivo: Comprender los sentimientos, sentidos, percepciones y perspectivas de usuarios frente al acceso a la vacunación en la Atención Primaria de Salud. Método: Se trata de un Estudio de Casos Múltiples Holístico-cualitativo, fundamentado en la Sociología Comprensiva del Cotidiano, con 74 representantes de cuatro microrregiones de la salud de la Región Ampliada Oeste del estado de Minas Gerais. La recolección de datos ocurrió entre junio 2016 y abril 2017. Para el análisis de los datos, se utilizó el Análisis de Contenido Temático, obedeciendo a la técnica de la síntesis cruzada de los casos. Resultados: Los resultados revelan los sentidos percibidos por los usuarios en la vivencia de vacunación y los sentimientos frente a la atención, evidenciando que las relaciones interpersonales entre la población y los profesionales de salud son determinantes en el acceso a la vacunación. La constante ampliación del calendario básico de inmunización amplió el acceso. Sin embargo, aspectos como los geográficos y sociales, la falta de conocimiento sobre vacunación y la recurrente falta de inmunobiológico fueron referidos como barreras al acceso a la inmunización. Consideraciones finales: Se resalta la necesidad de reforzar políticas más equitativas y la comunicación efectiva como medio de promover la credibilidad de los servicios junto a los usuarios.

Palabras clave: Accesibilidad a los Servicios de Salud; Vacunación; Atención Primaria de Salud; Satisfacción del Paciente. 


\section{INTRODUCTION}

This analysis can be extrapolated to other manifestations of everyday life. When considering the subject's opinion about the object, one should rather consider a path of experiences and affections. It is about thinking in terms of emotional rather than just reasonable people. ${ }^{1,2}$ Emphasis is given on embodied knowledge, that is, it does not necessarily pass through explanation or verbalization. This is the foundation of the comprehensive perspective..$^{2,3}$

Hence, the daily routine in vaccine rooms should be interactive. The nursing team should offer special care and safe vaccination; it should also welcome people and build bridges, establishing trust in the provision of vaccination assistance. "It is necessary to value the multiplicity of small things", 1:148 not only of emotions, but also of intellect and daily life where life is produced, an open reason in the sense of valuing life. ${ }^{1}$

Considering the value to life, the user has the right to universal, comprehensive and equitable access to health, considering the scope of actions, among them, the prevention of diseases. Access to immunoprevention in Brazilian public health is a population right, according to the basic immunization schedules of the National Immunization Programme (NIP).,

Immunization as a primary prevention measure has been shown to be one of the most successful and cost-effective interventions in producing an impact on vaccine-preventable diseases, promoting significant changes in the epidemiological profile worldwide. . $^{4}$

Although the level of approval and knowledge about vaccination is adequate, studies show that the use of immunization services is low, with vulnerable groups with vaccine coverage falling short of what is recommended, which leads to risks to individual and collective protection. ${ }^{7,8}$

Several factors have the potential to affect the use of immunization services, representing barriers to current vaccination. Among these factors are social determinants, attitudes and knowledge of users regarding vaccination, geographical location of health units in relation to the users' residence and the interpersonal relationship established between population and professionals working in Primary Health Care (PHC), which includes a subjective question that is the level of satisfaction or dissatisfaction of users with service..$^{7-9}$

The user's satisfaction in relation to health services is one of the essential elements for the evaluation of services and refers to acceptability scope. This scope is difficult to measure because it understands the nature of services provided and the way they are perceived by users, as well as the acceptance of professionals in providing services to that population. Acceptability can also be affected by aspects related to the accessibility dimension, which refers to the location of the offer in relation to users and resources for transportation. ${ }^{10}$

Studies show that satisfaction with services is not only related to reaching the resolution of demand presented, but also to the fact that their needs are considered and have presented the capacity to lead to an improvement in the quality of life of the population, since promotes adherence to care and continuity in the use of health services. ${ }^{9-11}$

Knowledge of factors intervening the access to vaccination services contributes to the planning of vaccine promotion measures, so the question is: how do users feel about access to vaccination in $\mathrm{PHC}$ ? What are the perceptions and perspectives of users regarding the reality of access to vaccination in $\mathrm{PHC}$ ?

The objective of this study was to understand the feelings, senses, perceptions and perspectives of users regarding access to vaccination in Primary Health Care.

\section{METHODOLOGY}

This is a Holistic-Qualitative Multiple Case Study, ${ }^{12}$ based on the theoretical framework of Comprehensive Sociology of Everyday Life. ${ }^{3}$ Understanding that open reason integrates its opposite is the fundamental presupposition for understanding. "Understanding does not seek first cause and effect, it does not have the chimera of 'why'. Through the 'as', limiting herself to the presentation of things, she endeavors to understand the internal signification of the observed phenomena". 1:220

The study setting was the Western Extended Region of Minas Gerais, which is composed of 54 municipalities, grouped in six health microregions. The multiple cases of this study were defined by the setting, constituting four of these microregions, determined by the saturation criteria of the data by literal replication. ${ }^{11}$ When the saturation was confirmed the data collection was closed.

In order to obtain representativity of different realities, and in order that the results may have the capacity for generalization in qualitative research, within each microregion, the municipalities were previously classified in terms of population size, Family Health Strategy (FHS) coverage, number of vaccine and territorial extension.

The selected municipalities, from the four microregions, present divergent characteristics in relation to the selection criteria defined a priori, being three large, two medium-sized and two small. Two have $100 \%$ population coverage of $\mathrm{FHS}$ and five have FHS population coverage of less than 100\%. Among these municipalities, the number of vaccine rooms ranged from two to 35 rooms and there was variation in relation to territorial extension.

The number of cases considered necessary in Multiple Case Studies should take into account a discretionary judgment. That is, the number of replications will be conditioned to the level of certainty that is wanted to obtain. The logic of discretionary judgment, in order to define the number of sufficient cases, parallels the logic of studies without case that establish criteria to define a "meaningful effect" in experimental science. Similarly, "the designation of the number of replications in Multiple Case Studies depends on the certainty that one wishes to obtain about the results and the meanings that bring the researched reality". ${ }^{12: 64-65}$ 
In this study, the level of certainty was affirmed with data collection in the fourth microregion of health. Data collection was closed after confirmation of data saturation by literal replication ${ }^{12}$ and by finding that the data collected were sufficient to meet the proposed method and objective. Therefore, seven municipalities and 25 PHC units were included, representing four health microregions in the Western Extended Region of Minas Gerais. The units visited were randomly selected.

An individual case study was carried out in each of the microregions, so each case in particular consists of a "complete" study in which convergent or divergent evidence is sought regarding the facts and conclusions for the case. The case studies have the capacity to generalize the theoretical propositions, that is, they make possible the analytical generalization. Thus, the findings of this study have the potential capacity to extend to similar situations, conferring external generalization.

Participants were 74 people who attended health units for vaccination or other care at the time of data collection, whose participation was voluntary. We adopted as inclusion criteria to be 18 years of age or older. We excluded persons temporarily or permanently unable to respond legally for their acts. A total of 82 approaches were performed, and eight users refused to participate in the study.

We used the intensive individual interview with a semistructured script as a source of evidence of data that approached the user regarding access to vaccination in $\mathrm{PHC}$; technical visits to vaccine rooms, and field notes for recording technical visit data, and for operational research development notes. A priori, the interview script was pre-tested.

Data collection took place from June 2016 to April 2017. The interviews had an average duration of ten minutes, they were performed according to the availability of users in private space in the health unit and were recorded in a digital file and later transcribed literally, preserving the reliability of information.

We used the Thematic Content Analysis framework for data analysis, ${ }^{13}$ obeying the analytical technique of cross-synthesis of the cases in consonance with the methodological framework of the Holistic-Qualitative Multiple Case Study. ${ }^{12}$ The study participants were identified by alphanumeric codes symbolized by the letter "I" (of interviewee), followed by the interview number of the participant in a sequential way and by one of the numbers $1,2,3$ or 4 , corresponding to the four sanitary microregions, cases confidentiality of information and anonymity of individuals and microregions.

This research was approved under Opinion 1,193,584, CAAE (Certificate of Presentation for Ethial Consideration): 47997115.2.0000.5545, in addition to being part of the Integrated Project, approved by the PPSUS (Process CBB-APQ-03509-13), PreveNIr: Quality evaluation of the National Immunization Programme in the Health Western Extended Region of Minas Gerais, which is articulated and deployed in this research. This research was developed according to the directives and norms regulating research involving human beings, according to Resolution of the National Health Council (Conselho Nacional de Saúde) 466/2012.

\section{RESULTS}

Of the 74 participants in this study, 63 (85.1\%) were female. Age ranged from 19 to 67 years, with a mean of 38.7 years. The predominant age group was 26 to 33 years (32.4\%). Most of the participants $(85.1 \%)$ live in urban areas and are Catholic $(78.4 \%)$.

The notion of access in the vaccine room was revealed as the facility to obtain the vaccine in a timely manner so that immunity is guaranteed as established by the NIP, as well as being a constitutional right of all.

[...] it is you having access, is to need a certain vaccine and you to be taken care of, to have in the unit the vaccine that is in the campaign, which will complete your vaccination card, that you will get immune within what the Ministry of Health asks (17-1).

\section{[...] access would be facility in you taking a dose of vaccine} (119-2).

[...] I understand that access is a right that every Brazilian must have, right? Of being protected against an illness, for free. It has to be done quickly, that meets the needs of each person and that is clarified more on the importance of the vaccine (122-2).

By declaring their perceptions and perspectives vis-à-vis the lived reality of access, users revealed the constant lack of immunobiological units.

[...] I always got the vaccines, always. Sometimes not the same day, but so, within a week there already had (I26-1).

[...] I think I need to change no. Just the fact of having all the vaccines, right? Affordable for everyone. There should always have (129-2).

[...] to tell you the truth, I really like the service here. [...] it happens sometimes to look for and not really have the vaccine, but so it is a thing to wait for a week [...] the longest I've ever waited for was a week or two. [...] I've been to this health center for six years, and for me, it's been great. Because it happens like this, you arrive and not have the vaccine, but always they have the date for you to return, and always on the date that we have back (163-4).

From the perspective of users, the senses perceived in the reality experienced in vaccination and feelings in front of service in the vaccine room appear:

[...] every time I came here, I was well served; I have never had a problem. Even because the person who vaccinates my son, the nurse, she plays, she is very affectionate, it pleases me too, she plays with my son and makes him very calm (I27-1). 
[...] up there I'll tell you, I don't like it, I don't take them even to vaccinate [...] I don't like their service [...] last time I took her to get vaccinated, never again! I still asked him if he could take it in the other units, he said he could, because there I will not take it anymore. I even thought: did she give the wrong vaccine? (117-2)

[...] for me it was always very easy (access). [...] I feel well served, very polite people, very accurate in what we want (121-2).

[...] here, in this health center, I was always well served; I always liked the service (165-4).

The meaning of vaccination and the reasons for getting vaccinated:

[...] you take the vaccine when you're still healthy to avoid, right? For the vaccine to take the risk of strong diseases (113-1).

[...] for me it is very important because vaccination prevents many diseases, so the beginning of everything is there. Because if you vaccinate a child or elderly will be preventing and giving health, prevents people from being hospitalized, avoid aggravating people's health (151-3).

From the participants' perception of the present study, vaccination is a social right. However, the availability criteria by age groups and priority groups established by the NIP, especially in relation to the influenza vaccine, was expressed as a factor that undermines this principle and restricts access.

[...] one thing I don't agree with is the H1N1 vaccine. They stipulated the people who could take. [...] I think it's a risky disease for everyone, so everyone had to take it. Everyone should have the right to taker (17-1).

[...] I think it had to be a more comprehensive campaign for everyone. Because even when you had H1N1, I was able to take the vaccine because I was pregnant and my child could not take it. As a mother I felt strange, I am being vaccinated and my son is not. I think it had to be broader. More availability, more vaccine, a more broad access (169-4).

Unavailability of some immunobiologicals in the basic vaccination schedules of the public network generated dissatisfaction. Many parents have revealed the desire to vaccinate their children, but because of financial limitations they cannot have access to vaccines offered in the private market.

[...] of course the government cannot afford all vaccines, so my biggest problem is buying the vaccines (111-1).

[...] the vaccines that are paid, these my boys did not take no, because I cannot afford to pay. As for the meningitis vaccine, I, for example, did not vaccinate them, because it was expensive for me to pay. These payments I wanted to vaccinate my children, but I could not (143-3).

[...] something ideal would be the system to make available vaccines that the population seeks, because often the parents have to buy from outside, not all the vaccines that the system provides. There are expensive vaccines that not every population can buy (171-4).

On the other hand, the constant expansion of the basic immunization schedule and, consequently, the expansion of access, were evidenced.

[...] look, in the past, how many people had paralysis, right? Today it no longer exists because of the vaccine. [...] access is broader nowadays, right? For my daughter, in the old days, I used to pay, besides the appointment, the flu vaccine, now the vaccine is available (140-3).

[...] for my eldest girl, there was no chickenpox vaccine, so I paid for it, but I already had the chickenpox vaccine, so I did not even have to pay. So I think the vaccines are pretty wide (141-3).

[...] for the older one I had to pay, because I had a vaccine that I did not have before, did I? But today, with my youngest daughter, the ones I paid at the time of the eldest, today I don't pay because there is already in the health center (165-4).

Aspects related to geographical location of the offer in relation to the users' homes emerged as a factor that directly influences access to health services. The distance between the PHC and the users' home, the lack of public transport and barriers along the way were pointed out as making access difficult. When the PHC was located in the neighborhood where the registered families resided the access was facilitated.

[...] for me, the location is difficult, because the health center is in another neighborhood and it is in the last street of the neighborhood, it is very difficult, and there are no buses there, you have to go by foot. It's too dense; there are three hills (118-2).

[...] no, where I live there is not (vaccine room), I'm registered right here. I have to come here. Sometimes it's complicated. [...] it would be easier if there was an unit where I live (I36-3).

[...] my house is close, I live two blocks away from here, it's easy. I have this advantage, it's close, just going down, nor does it need transportation. (111-1).

[...] I live here very close, then I don't spend difficulty in this matter of not having as I come, because as it is, there I see no difficulty, it is easy (144-3). 
Social aspects have emerged as barriers to access to vaccination, such as fragility in family structure, involvement with work activities and commitments, and myths related to vaccines adverse events.

[...] because I don't have a mother, you know? I lost my mother at the age of 5 months. Then I lived with my grandmother, after my grandmother died I came to live with my sister, then my card disappeared on this coming trip. I lost my card on those trains. Then I have nothing. When I was very young even though I took the last vaccine. After that I never took it (I3-1).

[...] because nowadays we live in a very complicated economic situation in the country, don't we? Then people will worry about maintaining their business, keeping their life stable. Pay your bills on time. So, speaking for me, I would not leave my job today to get vaccinated (I8-1).

[...] so I did not take (the Influenza vaccine) because it was cause the opposite reaction. Like, the person took it and got the flu, that's what the people were talking about, so I decided not to take it. [...] can be a reaction of the vaccine itself, I don't know (I20-2).

We also pointed the fear of needle as a factor that can interfere in the search and vaccination. It should be noted that in these situations, the professionals who work in the vaccine room play a fundamental role, as evidenced in the speech of one of the participants.

[...] I hate vaccine, I hate injection, but they leave me so comfortable that I go, even afraid of the injection. They go on talking to me and when I see until I have vaccinated. It's very tranquil, isn't it? I very much praise this center, because I think they deserve to be praised, you know? Because they also have a lot of security in what they are doing. So for me, although I don't like it, I go quiet because I trust their work (I35-2).

[...] I'm a little scared, I think it's normal, isn't it? Fear of the same needle. As much as we have to be always up to date with vaccination, I particularly am picky only with the needle, not with the medicine. Sometimes I get here (in the health unit) and go away, that's how it is ... I'm very much aware, understand? (158-3)

[...] my husband's card is not up to date, he rushes through the needle. His card is white, there are two injections only, he's afraid of injection (160-4).

The collaborative knowledge of the professional was expressed by the research participant:

[...] regarding vaccines, I think it is very difficult for people to record; there are innumerable vaccines, isn't it? [...] my card should not be up to date completely, for this reason nobody understands vaccination. What vaccines should I be taking? What vaccines and in what age range should I have taken? [...] of an age group, from such an age to another you have to take the $X$ vaccine, given the second stage of your $Y$ vaccines life. For those who don't work in the health field, they will not really understand (I8-1).

Below is the user's interest to follow and know the vaccine preparation and safety of the procedure to be performed:

[...] I find it difficult to take the vaccines and not be able to keep up. Where I vaccinate, she picks up the card, prepares the vaccine first, and when it's ready, she calls to apply. I just want to keep up with what she's doing, only. [...] I wanted to see what they do, if they are doing it right, what's going on. Because I get there and everything is ready. How do I know if everything's all right? (118-2)

\section{DISCUSSION}

Access to health, a complex and multidimensional process, refers to the relationship between the care needs of a given population and the ability of the system to provide health services equitably in a timely manner. Although it is a right enshrined in the Federal Constitution, it remains one of the major concerns and one of the greatest challenges related to the Brazilian Unified Health System (Sistema Único de Saúde) organization and implementation process. ${ }^{14-16}$ Access in the vaccine room was revealed by the participants of this research as a constitutional right of all, and should be easy to obtain and in a timely manner.

By declaring their perceptions and perspectives of access to reality, the users evaluated that the access to vaccine room occurs in an adequate and satisfactory way, despite evidencing the constant lack of immunobiological in the health units. This result, although contradictory, shows that being satisfied with health services is not only related to the access or technical quality of the assistance received, but also to the quality of relationships established. "Life is lived in the form of greed. It is no more than a simple consumption, but an intense consummation", 17:23 where each one is an actor and, at the same time, a spectator, in the daily interrelationships. Therefore, "the way the user is treated by the team members presents itself as a central issue for the PHC quality judgment". $9: 324$

Vaccination meets the criteria of availability by age group and priority groups, according to the basic schedules of the NIP, prioritizing the most susceptible, which confers equity in access. However, because the study participants did not understand the criteria, they indicated that this is a factor that restricts universal access to immunization. It is worth noting that the decision to include or exclude vaccinations offered and the population of choice is supported by technical and scientific bases, such as cost-effectiveness studies, immunobiological safety, production capacity of laboratories and the feasibility of distribution and storage..$^{18,19}$ 
Great dissatisfaction was revealed by the participants of the present study regarding unavailability for the entire population of Influenza vaccine. The Influenza vaccine has been offered since 1999 by the Ministry of Health of Brazil, through annual campaigns to target populations, ${ }^{4}$ and since its introduction, there has been a significant reduction in hospitalizations due to Influenza-related causes, especially in the elderly population, ${ }^{20}$ directly impacting the reduction of hospitalization costs due to complications of the disease. It is therefore incumbent upon health professionals to actively act on the guidelines on specific indications and recommendations of each vaccine, in order to promote the credibility of the NIP with the population, and to comply with the principles of accessibility and equity through higher risk criteria.

Unavailability of some immunobiologicals in the basic vaccination schedules of the Brazilian public network was also a factor that generated dissatisfaction among study participants, who due to financial limitations do not have access to vaccines offered in the private market. A similar result was found in a study carried out in a Minas Gerais municipality, where the parents' anxiety about not being able to offer certain vaccines to their children was revealed. ${ }^{21}$

However, the constant expansion of the NIP vaccination schedule and the consequent increase in access to immunization was evidenced in this study. Due to the constant advance of science and technology, changes in the country's epidemiological situation, and the economic measures adopted by the Ministry of Health, the NIP has gradually expanded the supply of vaccines and expanded access through changes in its indications. ${ }^{4}$

The reorganization of PHC in Brazil through the Family Health Strategy (FHS) and the expansion of primary network services have demonstrated substantial advances in the field of public health, in predicting the construction of friendly relationships and the link between health professionals and populations of delimited territories, which reduced geographic access barriers and promoted the regular use of health services offered by PHC. 22,23

However, the distance as a geographical obstacle to access was mentioned. The distance between users' homes and health facilities reduces the chance of users being satisfied with health services. ${ }^{11}$

Concerning social aspects, involvement with work activities and commitments, fragility in the family structure, and fear of possible vaccine-related adverse events emerged as barriers to access to vaccination.

Fear of possible vaccine adverse events, according to Italian university students, may be related to emotional factors and inadequate information that entail distorted perceptions about the real risks and benefits associated with vaccination. ${ }^{24}$

Post-vaccination adverse events occur more frequently in children less than one year of age and may manifest in a systemic and local way, the hypotonic episode being hyporresponsive, induration, fever, pain, flushing and heat the most common reactions. However, such events evolve in more than $99.0 \%$ of cases to cure without causing sequel or greater damage to individuals, showing that the benefits of immunization outweigh the risks. 25,26

Work is an important component in people's lives, and long hours of work may represent barriers in the search for and obtainment of preventive health care. In addition, individuals may also forgo health care because they believe they are not important, or because they are engaged in other competing activities and commitments. In this sense, health professionals, especially those working in $\mathrm{PHC}$ settings, should be aware of this barrier to access to health care, in order to promote specific strategies for access to this public. ${ }^{27}$

There is a decreasing trend in vaccination coverage related to the fact that it is a member of groups with low social inclusion, belonging to large families and low educational level of the parents, causing an increase in the susceptibility of noncompliance with vaccination schedules due to the presence of mechanisms that compromise the access to goods and services. ${ }^{8}$

The present research revealed that the non-satisfaction of the user with the care received in PHC causes a feeling of insecurity regarding the care received, compromising the return and access to this service. Another research that aimed to identify the main factors that influence user satisfaction in Brazilian PHC services has demonstrated that the lack of commitment, respect and attention of the professional and the user's perception that the health team did not seek to meet their needs are among the main causes of users' dissatisfaction with health services. ${ }^{11}$

Interests in following all the steps that precede the immunobiological administration were evidenced as a factor with the potential to promote confidence in the safety of the procedure. Attention should be focused on an increasing need to develop a more open communication between health professionals and users, facilitating a better quality of relationships and consequently adherence to care. ${ }^{11}$

A study that aimed to identify the vaccination profile of adult users of a FHS in Caxias-MA, Brazil, also showed that the fear of adverse reactions of the vaccine, as well as the fear of the needle at the injection, appeared as factors that interfere in the adherence to the vaccination, ${ }^{28}$ corroborating with the findings of the present study. The "emotional, in this case, is based on common feelings in shared experience, collective experience". ${ }^{29: 96}$ The lack of knowledge by the user about vaccination has emerged as a factor that compromises access to this service. Although the "use of the media as a source of information on preventive measures, including vaccination" has been increasingly evidenced, ${ }^{30: 126}$ there is a need to strengthen health education actions that reach the different social strata. The "consolidation of preventive attitudes of risks and injuries must be in a continuous process, where it is understood that health education must be permanent, built throughout life, in relationships at work, social, and among people who share to live in society. The process of continuous learning leads to new 
conceptions, attitudes and possibilities in the re-creation of one's own way of being and taking care of oneself". 31:sp Communication is what binds us to the other, it is implicit in sociality. Therefore, it is capable of providing transformation, education and awareness. ${ }^{32}$ It is considered that effective information and communication are essential to reach the preventive measure of vaccination as a protector of individual and collective health.

\section{FINAL CONSIDERATIONS}

This study made it possible to understand the aspects related to acceptability and access accessibility dimensions, considering the subjectivity expressed in the feelings, senses, perceptions and perspectives of the users regarding the experience in vaccination in the PHC. The analysis of individual and collective experiences, in the context studied, revealed that the quality of relationships established between professionals and users is determinant for satisfaction with health services.

Vaccination was expressed as a social right, and the unavailability of some immunobiologicals in the public network, as well as availability criteria by age group and priority groups, were understood as restricting access factors. In this sense, we highlight the need for efficient and interactive communication between professionals and users to report on recommendations and indications specific to each immunobiological.

Fear of possible adverse vaccine events was reported as a factor that compromised access to immunization. It reinforces the need for efficient communication that promotes people's safety in the face of the preventive measure of vaccination, such as the credibility of the PNI with the population and enables users to know about the real risks and benefits related to vaccines.

Socioeconomic and geographical aspects have also emerged as determinants of access to vaccination. Knowledge of these factors contributes to the planning of vaccine promotion measures tailored to the unequal, and indicates the need to reinforce more equitable policies.

The results indicate contributions to Health and Nursing, presenting subsidies so that the professionals can have a look at the feelings, senses, perceptions and perspectives of the users in front of the access in the vaccine room in order to promote a more equal access.

Considering the importance of the subject under study in Public Health, it is necessary to carry out other researches that, like this one, seek the understanding of possible bottlenecks from the user's point of view. As it turned out, such an approach in assessing the use of immunization services is still incipient.

\section{FINANCIAL SUPPORT}

This study was financed by the Announcement 14/2013 of the Research Program for SUS (PPSUS), Process CBB-APQ-03509-13.

\section{REFERENCES}

1. Maffesoli M, Poe AE. Elogio da razão sensível. 4ª ed. Petrópolis: Vozes; 2008.

2. Maffesoli M. A terra fértil do cotidiano. Rev Famecos [Internet]. 2008; [cited 2017 Nov 15]; 15(36):5-9. Available from: http://revistaseletronicas. pucrs.br/ojs/index.php/revistafamecos/article/view/4409/3308

3. Maffesoli M. O conhecimento comum: introdução à sociologia compreensiva. Porto Alegre: Sulina; 2010.

4. Ministério da Saúde (BR). Secretaria de Vigilância em Saúde. Departamento de Vigilância das Doenças Transmissíveis. Programa Nacional de Imunizações: 40 anos. Brasília (DF): Ministério da Saúde; 2013 [Internet]. Available from: http://bvsms.saude.gov.br/bvs/ publicacoes/programa_nacional_imunizacoes_pni40.pdf

5. Ministério da Saúde (BR). Secretaria de Vigilância em Saúde. Departamento de Vigilância das Doenças Transmissíveis. Manual de Normas e Procedimentos para Vacinação [Internet]. Brasília (DF) Ministério da Saúde; 2014 [Internet]. Available from: http://www.saude. pr.gov.br/arquivos/File/-01VACINA/manual_procedimentos_2014.pdf

6. Barreto ML, Teixeira MG, Bastos FI, Ximenes RAA, Barata RB Rodrigues LC. Successes and failures in the control of infectious diseases in Brazil: social and environmental context, policies, interventions, and research needs. Lancet [Internet]. 2011; [cited 2017 Nov 8]; 337:1877-1887. Available from: https://www.researchgate.net/ publication/284491158_Sucessos_e_Fracassos_no_Controle_de_ Doencas_Infecciosas_no_Brasil_O_Contexto_Social_e_Ambiental_ Politicas_Intervencoes_e_Necessidades_de_Pesquisa

7. Ababu Y, Braka F, Teka A, Getachew K, Tadesse T, Michael Y, et al. Behavioral determinants of immunization service utilization in Ethiopia: a cross-sectional community-based survey. Pan Afr Med J [Internet] 2017 Jun; [cited 2017 Dec 17]; 27(Suppl 2):2. Available from: https:// www.ncbi.nlm.nih.gov/pubmed/28983390

8. Oliveira MFS, Martinez EZ, Rocha JSY. Fatores associados à cobertura vacinal em menores de cinco anos em Angola. Rev Saúde Pública [Internet]. 2014; [cited 2017 Sep 4]; 48(6):906-15. Available from: http:// www.scielo.br/pdf/rsp/v48n6/pt_0034-8910-rsp-48-6-0906.pdf. DOI: http://dx.doi.org/10.1590/S0034-8910.2014048005284

9. Arruda CAM, Bosi MLM. Satisfação de usuários da atenção primária à saúde: um estudo qualitativo no Nordeste do Brasil. Interface (Botucatu) [Internet]. 2017; [cited 2018 Jan 2]; 21(61):32132. Available from: http://www.scielo.br/scielo.php?pid=S141432832017000200321\&script=sci_abstract\&tlng=pt

10. Penchansky R, Thomas JW. The Concept of Access: Definition and Relationship to Consumer Satisfaction. Med Care [Internet]. 1981 Feb;19(2):127-40. Available from: https://www.ncbi.nlm.nih.gov/ pubmed/7206846

11. Protasio APL, Gomes LB, Machado LS, Valença AMG. Fatores associados à satisfação de usuários com a atenção primária à saúde no Brasil. Cad Saúde Pública [Internet]. 2017; [cited 2017 Dec 13]; 33(2) e00184715. Available from: http://www.scielo.br/pdf/csp/v33n2/16784464-csp-33-02-e00184715.pdf. DOI: http://dx.doi.org/10.1590/0102$311 \times 00184715$

12. Yin RK. Estudo de Caso: Planejamento e métodos. Tradução de Cristhian Matheus Herrera. $5^{\mathrm{a}}$ ed. Porto Alegre: Bookman; 2015.

13. Bardin L. Análise de conteúdo. São Paulo: Edições 70; 2011

14. Cassiani SHB. Strategy for universal access to health and universal health coverage and the contribution of the International Nursing Networks. Rev Lat Am Enferm [Internet]. 2014 Nov/Dec; [cited 2017 Dec 15]; 22(6):891-2. Available from: http://www.scielo.br/scielo. php?script=sci_arttext\&pid=S0104-11692014000600891

15. Viegas SMF, Penna CMM. O SUS é universal, mas vivemos de cotas. Ciênc Saúde Coletiva [Internet]. 2013; [cited 2017 Oct 13]; 18(1):181-90. Available from: http://www.scielo.br/pdf/csc/v18n1/19.pdf. DOI: http:// dx.doi.org/10.1590/S1413-81232013000100019. 
16. Assis MMA, Jesus WLA. Acesso aos serviços de saúde: abordagens, conceitos, políticas e modelo de análise. Ciênc Saúde Coletiva [Internet]. 2012; [cited 2017 Jun 20]; 17(11):2865-75. Available from http://www.scielo.br/pdf/csc/v17n11/v17n11a02.pdf. DOI: http://dx.doi. org/10.1590/S1413-81232012001100002.

17. Maffesoli M. O instante eterno: o retorno do trágico nas sociedades pós-modernas. São Paulo: Zouk; 2003.

18. Domingues CMAS, Teixeira AMS. Coberturas vacinais e doenças imunopreveníveis no Brasil no período 1982-2012: avanços e desafios do Programa Nacional de Imunizações. Epidemiol Serv Saúde [Internet]. 2013 Jan/Mar; [cited 2017 Nov 21]; 22(1):9-27. Available from: http://scielo.iec.gov.br/pdf/ess/v22n1/v22n1a02.pdf. DOI: http:// dx.doi.org/10.5123/S1679-49742013000100002

19. Jauregui B, Garcia AG, Bess Janusz C, Blau J, Munier A, Atherly D, et al. Evidence-based decision-making for vaccine introductions: Overview of the ProVac International Working Group's experience. Vaccine [Internet]. 2015 May; [cited Nov 201721];33(Suppl 1):A28-33. Available from: https://www.ncbi.nlm.nih.gov/pmc/articles/PMC4624336

20. Daufenbach LZ, Duarte EC, Carmo EH, Campagna AS, Santos CAST. Impacto da vacinação contra a influenza na morbidade hospitalar por causas relacionadas à influenza em idosos no Brasil. Epidemiol Serv Saúde [Internet]. 2014; [cited 2017 Aug 12]; 23(1):9-20. Available from: http://www.scielo.br/pdf/ress/v23n1/2237-9622-ress-23-01-00009.pdf. DOI: http://dx.doi.org/10.5123/S1679-49742014000100002

21. Ferreira AV, Oliveira CF, Guimarães EAA, Cavalcante RB, Moraes JT, Oliveira VC. Acesso à sala de vacinas nos serviços de atenção primária à saúde. Rev Eletr Enferm [Internet]. 2017; [cited 2017 Nov 15]; 19a:31. Available from: https://www.revistas.ufg.br/fen/article/ viewFile/42468/24010. DOI: https://doi.org/10.5216/ree.v19.4246822

22. Fertonani HP, Biff D, Scherer MDA. The health care model: concepts and challenges for primary health care in Brazil. Ciênc Saúde Coletiva [Internet]. 2015; [cited 2017 Nov 25]; 20(6):1869-78. Available from: http://www.scielo.br/pdf/csc/v20n6/en_1413-8123-csc-20-06-1869. pdf. DOI: http://dx.doi.org/10.1590/1413-81232015206.13272014.

23. Almeida PF, Fausto MCR, Giovanella L. Fortalecimento da atenção primária à saúde: estratégia para potencializar a coordenação dos cuidados. Rev Panam Salud Publica [Internet], 2011 [cited 2017 Jun 20]; 29(2):84-95. Available from: http://www6.ensp.fiocruz.br/ repositorio/sites/default/files/arquivos/Fortalecimento.pdf
24. Provenzano S, Santangelo OE, Lanza GLM, Raia DD, Alagna E, Firenze A. Factors associated with reporting adverse reactions after immunization, study in a sample of university students. Ann Ig [Internet] 2018 Sep/Oct; [cited 2018 Sep 7]; 30(5):436-42. Available from: https:// www.ncbi.nlm.nih.gov/pubmed/30062372

25. Silva SS, Oliveira VC, Ribeiro HCTC, Alves TGS, Cavalcante RB, Guimarães EAA. Análise dos eventos adversos após aplicação de vacinas em Minas Gerais, 2011: um estudo transversal. Epidemiol Serv Saúde [Internet]. 2016 Jan/Mar; [cited 2018 Sep 10]; 25(1):4554. Available from: http://www.scielo.br/pdf/ress/v25n1/2237-9622ress-25-01-00045.pdf

26. Santos MCS, Netto VBP, Andrade MS. Prevalência e fatores associados à ocorrência de eventos adversos pós-vacinação em crianças. Acta Paul Enferm [Internet]. 2016; [cited 2018 Sep 10]; 29(6):62632. Available from: http://www.scielo.br/scielo.php?pid=S0103 21002016000600626\&script=sci_abstract\&tlng=pt

27. Yao X, Dembe AE, Wickizer T, Lu B. Does time pressure create barriers for people to receive preventive health services. Prev Med [Internet] 2015 May; [cited 2018 Jan 7]; 74:55-8. Available from: https://www. ncbi.nlm.nih.gov/pubmed/25773470

28. Chaves LHS, Ross JR. Perfil vacinal de adultos cadastrados em uma microárea da Estratégia Saúde da Família. Rev Enferm UFPI. [Internet]. 2014; [cited 2017 Dec 15]; 3(4):4-9. Available from: http:// www.ojs.ufpi.br/index.php/reufpi/article/view/1845/pdf. DOI: http:// dx.doi.org/10.26694/reufpi.v3i4.1845

29. Maffesoli M. No fundo das aparências. Porto Alegre: Vozes; 1996

30. Osis MJD, Duarte GA, Souza MH. Conhecimento e atitude de usuários do SUS sobre o HPV e as vacinas disponíveis no Brasil. Rev Saúde Pública [Internet]. 2014; [cited 2017 Oct 7]; 48(1):123-33. Available from: http://www.scielo.br/pdf/rsp/v48n1/0034-8910-rsp-48-01-0123. pdf. DOI: http://dx.doi.org/10.1590/S0034-8910.2014048005026

31. Viegas SMF, Sampaio FC, Oliveira PP, Lanza FM, Oliveira VC, Santos WJ.Vacinação e o saber do adolescente: Educação em saúde e ações para a imunoprevenção. Ciênc Saude Coletiva [Internet]. 2017; [cited 2018 Jan 8]. Available from: http://www.cienciaesaudecoletiva.com.br/ artigos/vacinacao-e-o-saber-do-adolescente-educacao-em-saude-eacoes-para-a-imunoprevencao/16390

32. Maffesoli M. A comunicação sem fim (teoria pós-moderna da comunicação). Rev Famecos [Internet]. 2003; [cited 2018 Jan 5] 10(20):12-20. Available from: http://revistaseletronicas.pucrs.br/fzva/ ojs/index.php/revistafamecos/article/view/3198/2463 